\title{
Pelatihan Merakit dan Instalasi Laptop/Komputer pada Santri Yayasan Pendidikan Islam Pondok Pesantren Wali Songo Banjarbaru
}

\author{
Training on Assembling and Installing Laptops/Computers at the Santri Islamic Education \\ Foundation of Wali Songo Islamic Boarding School, Banjarbaru
}

Tri Wahyu Qur'ana*
Al Fath Riza Kholdani
Hayati Noor
Department of Informatics
Engineering, Universitas Islam
Kalimantan Muhammad Arsyad Al
Banjari Banjarmasin, Banjarmasin,
South Kalimantan, Indonesia

"email: twqurana@gmail.com
Kata Kunci
Instalasi
Komputer
Laptop
Perakitan
Keywords:
Installation
Computer
Laptop
Assembly
Received: February 2020
Published: September 2020

\begin{abstract}
Abstrak
Merakit komputer merupakan suatu tahapan kegiatan menyatukan komponen-komponen yang dibutuhkan agar komputer dapat berjalan dengan baik. Untuk memahami proses perakitan komputer yang benar, dibutuhkan pemahaman terhadap perangkat keras komputer baik secara logical dan physical. Sementara itu agar komputer dapat dioperasikan sesuai dengan fungsinya perlu dilakukan instalasi. Instalasi komputer yaitu memasang program (perangkat lunak) ke dalam komputer. Semua perangkat lunak (misalnya Microsoft windows, Microsoft Office dan lainlain) selain itu, instal juga berfungsi untuk menyesuaikan program dengan alat-alat terpasang pada komputer dan menguraikan file-file yang dipadatkan. Keahlian merakit dan instalasi laptop/komputer mampu menjadikan ladang usaha ekonomi kreatif berbasis teknologi informasi. Yayasan Pendidikan Islam Pondok Pesantren Wali Songo adalah sebuah lembaga pendidikan agama islam. Santri sebagai pemuda generasi penerus bangsa, perlu memahami dan memiliki keterampilan dalam merakit dan instalasi laptop/komputer, bukan hanya sebagai pengguna pasif saja tetapi juga harus aktif, Sisi lain juga mampu dijadikan sebagai bagian dari penggerak ekonomi kreatif.
\end{abstract}

\begin{abstract}
Assembling a computer is a stage of bringing together the components needed to run correctly. To understand the correct computer assembly process, an understanding of computer hardware is required both logically and physically. Meanwhile, so that the computer can be operated according to its function, it is necessary to install it. Computer installation is installing a program (software) into a computer. All software (e.g., Microsoft Windows, Microsoft Office, and others) apart from that, also install functions to match the program with the tools installed on the computer and parse the compressed files. The expertise in assembling and installing laptops/computers can make a creative economy business field based on information technology. The Islamic Education Foundation of Wali Songo Islamic Boarding School is an Islamic religious, educational institution. Santri, as the nation's next-generation youth, needs to understand and have skills in assembling and installing laptops/computers, not only as passive users but also being active, the other side can also be used as part of driving the creative economy.
\end{abstract}

(C) 2020 Tri Wahyu Qur'ana, Al Fath Riza Kholdani, Hayati Noor. Published by Institute for Research and Community Services Universitas Muhammadiyah Palangkaraya. This is Open Access article under the CC-BYSA License (http://creativecommons.org/licenses/by-sa/4.0/). DOI: https://doi.org/10.33084/pengabdianmu.v5i4.1270

\section{PENDAHULUAN}

Perkembangan teknologi saat ini berkembang dengan sangat pesat. Di mana, teknologi juga memiliki andil besar dalam perkembangan kehidupan manusia terutama komputer (Budiman, 2017). Merakit komputer merupakan suatu tahapan kegiatan menyatukan komponen-komponen yang dibutuhkan agar komputer dapat berjalan dengan baik (Herlandy et al., 2019). Untuk 
memahami proses perakitan komputer yang benar, dibutuhkan pemahaman terhadap perangkat keras komputer baik secara logical dan physical (Manurung \& Lenny, 2014). Sementara itu agar komputer dapat dioperasikan sesuai dengan fungsinya perlu dilakukan instalasi. Instalasi komputer yaitu memasang program (perangkat lunak) ke dalam komputer semua perangkat lunak (misalnya, Microsoft Windows, Microsoft Office, dan perangkat lunak lainnya). Selain itu, instalasi juga berfungsi untuk menyesuaikan program dengan alatalat terpasang pada komputer dan menguraikan file-file yang dipadatkan. Keahlian merakit dan instalasi laptop/komputer mampu menjadikan ladang usaha ekonomi kreatif berbasis teknologi Informasi (Anjrah et al., 2008; Arifianto \& Funatik, 2009; Daulay, 2007; Jogiyanto, 2005).

Proses merakit komputer sendiri memerlukan berbagai teknik dan prosedur perakitan yang benar agar komponen-komponen yang digabungkan dapat membentuk komputer secara kesatuan yang utuh sehingga bisa digunakan dan berjalan dengan normal. Oleh sebagian orang, merakit komputer dianggap sebagai kegiatan yang rumit dan hanya dilakukan oleh teknisi komputer yang ahli dibidangnya. Pandangan ini sebenarnya tidak sepenuhnya tepat karena merakit komputer sangat modular artinya bahwa pemasangan dan pembuatan yang sesuai dengan tiap komponen menggunakan standardisasi yang sama (Gumawang, 2006; Zaki \& SmitDev Community, 2007).

Pondok Pesantren (Ponpes) Wali Songo Banjarbaru, merupakan pondok pesantren salafiyah yang didirikan oleh KH. Muhammad Abdul Hamid Marzuqi S.Pd.I, M.M, beliau merupakan pendiri sekaligus pengasuh pondok pesantren ini. Pondok pesantren ini didirikan 1997 dan ditempati resmi di 2005. Awalnya Ponpes Wali Songo adalah ponpes yang hanya mengajarkan ajaran Islam. Namun atas masukan dari Habib Said Abdullah yang kini juga Sekdako Banjarbaru, Ponpes Wali Songo kini juga menyelenggarakan pendidikan formal. Ponpes yang memiliki dua jenjang sekolah umum yaitu Madrasah Tsanawiyah dan Madrasah Aliyah ini kini sudah memilki sekitar 400 siswa. Kegiatan-kegiatan santri selama ini banyak diisi dengan kegiatan keagamaan sehingga tidak banyak keterampilan yang mereka miliki sebagai bekal masa depan terjun ke masyarakat luas.

Pengelolaan komputer/laptop pada Ponpes Wali Songo Banjarbaru masih terbengkalai, terbukti tidak adanya tenaga atau ahli khusus mengelola peralatan komputer. Komputer/laptop yang bermasalah langsung dibawa ke tempat service untuk dilakukan perbaikan. Padahal hanya hal kecil, misalkan hanya menambahkan aplikasi yang diperlukan ponpes. Pembersihan virus komputer pun mereka belum dapat melakukankannya. Sangat diperlukannya pengelolaan hardware dan software komputer pada ponpes tersebut.

Solusi yang ditawarkan kepada para santri Pondok Pesantren Wali Songo Banjarbaru adalah pengembangan diri, penambahan wawasan dan bekal keterampilan dalam bidang teknologi informasi dan komunikasi. Kegiatan-kegiatan mereka selama ini banyak diisi dengan kegiatan keagamaan. Tidak banyak keterampilan yang mereka miliki sebagai bekal masa depan terjun ke masyarakat luas. Sebagai seorang santri di zaman sekarang bekal pengetahuan tentang komputer sangat diperlukan (Hidayat, 2010). Pelatihan ini akan membantu mereka menjawab tantangan jaman era teknologi digitalisasi terhadap komputer (Damanhuri et al., 2013). Terciptanya generasi penerus bangsa yang memahami dan mengetahui teknologi informasi dapat mereka jadikan sebagai usaha ekonomi kreatif (Azizah \& Muhfiatun, 2017). 


\section{METODOLOGI}

Metode pelaksanaan kegiatan pengabdian kepada masyarakat dilaksanakan melalui pelatihan dengan pemanfaatan modul yang telah disediakan yaitu dengan metode teori pembelajaran dan praktik langsung ditempat. Selain itu, mereka juga diberikan contoh dan kasus serta simulasi cara merakit laptop/komputer step by step dan instalasi beberapa software.

Melalui kegiatan pengabdian kepada masyarakat, pelatihan kepada peserta para santri Pondok Pesantren Wali Songo Banjarbaru dilakukan oleh beberapa instruktur profesional dibidangnya dengan materi pelatihan sebagai berikut:

1. Pengenalan dan Persiapan Komponen Komputer

2. Peralatan Merakit Komputer

3. Praktek Merakit Komputer

4. Pengujian Hasil Merakit Komputer

5. Instalasi Aplikasi dan Pengelolaan

6. Pengujian dan Implementasi Komputer

\section{HASIL DAN PEMBAHASAN}

Pelatihan ini memberikan beberapa materi tentang pengenalan komponen komputer, peralatan merakit komputer, praktek merakit komputer, pengujian hasil merakit komputer, instalasi aplikasi serta pengujian. Metode pelaksanaan kegiatan pengabdian kepada masyarakat dilaksanakan dengan pemberian pemberian materi. Selanjutnya langsung praktik langsung ditempat. Kemudian para peserta dipersilahkan merakit dan istalasi komputer.

Pelaksanaan program ini melibatkan dua orang mahasiswa agar kegiatan dapat berjalan lancar. Kegiatan tanya jawab dilakukan bersamaan dengan penyajian materi. Para peserta dapat langsung berdiskusi dengan para pemateri secara langsung untuk memahamkan materi dan saling berbagi pengalaman terkait dengan masalah yang tengah dibahas dalam materi bersangkutan. Pada pelaksanaan praktik merakit dan instalasi laptop/komputer peserta dibagi menjadi dua kelompok dan didampingi oleh tim. Kegiatan ini terlaksana di salah satu ruang kelas Ponpes WaliSongo Banjarbaru.

Materi yang disajikan oleh tim pengabdi dapat diterima, dicerna, dan dipahami peserta dengan baik. Pelaksanaan praktik merakit dan instalasi laptop/komputer juga berjalan dengan lancar. Jumlah peserta yang sebanding dengan jumlah pengabdi yang berperan sebagai instruktur dan tutor menjadikan pelatihan ini menjadi lebih kondusif.

Dari 20 orang santri yang didelegasikan untuk mengikuti kegiatan pengabdian kepada masyarakat ternyata 16 diantaranya berasal dari luar Banjarbaru, bahkan ada santri yang berasal dari Kalimantan Tengah, Pontianak Kalimantan Barat dan Pati Jawa Tengah. Sebelum kegiatan pengabdian kepada masyarakat berlangsung, mereka semua belum mengetahui bagaimana merakit dan instalasi laptop/komputer. Setelah kegiatan berlangsung mereka semua mengetahui tentang merakit dan instalasi laptop/komputer serta peluang usaha sebagai wadah ekonomi kreatif.

Evaluasi kegiatan pengabdian kepada masyarakat ini dilakukan dengan beberapa cara. Yang pertama, evaluasi hasil dilihat dari praktik mandiri oleh masingmasing peserta, dapat dilihat bahwa rata-rata peserta pelatihan telah mampu merakit dan melakukan instalasi laptop/komputer. Penilaian kedua didapat dari kuisioner pre-test post-test dengan 10 pertanyaan seputar merakit dan instalasi laptop/komputer yang menunjukkan peningkatan kemampuan yang signifikan pada tiap-tiap komponen materi pembahasan. Hasil pre-test dan post-test disajikan pada Tabel I. 
Tabel I. Pretest dan Posttest Kemampuan Peserta Pelatihan

\begin{tabular}{|c|c|c|c|}
\hline $\begin{array}{l}\text { Pokok Bahasan } \\
\text { (Materi) }\end{array}$ & $\begin{array}{l}\text { Pre } \\
\text { Test } \\
(\%)\end{array}$ & $\begin{array}{l}\text { Post } \\
\text { Test } \\
(\%)\end{array}$ & $\underset{(\%)}{\text { Peningkatan }}$ \\
\hline $\begin{array}{lr}\text { Komponen } & \text { Hardware } \\
\text { (perangkat } & \text { keras) } \\
\text { laptop/komputer }\end{array}$ & 0 & 73 & 73 \\
\hline Memori Komputer & 2 & 86 & 84 \\
\hline Upgrade komputer & 22 & 83 & 61 \\
\hline $\begin{array}{l}\text { Cara merawat } \\
\text { Motherboard }\end{array}$ & 10 & 87 & 77 \\
\hline $\begin{array}{l}\text { Perangkat input dan } \\
\text { output komputer }\end{array}$ & 16,5 & 89 & 72,5 \\
\hline $\begin{array}{l}\text { Alat yang dibutuhkan } \\
\text { untuk merakit } \\
\text { komputer }\end{array}$ & 10 & 67 & 57 \\
\hline $\begin{array}{l}\text { Cara merakit } \\
\text { laptop/komputer }\end{array}$ & 33 & 83 & 50 \\
\hline $\begin{array}{l}\text { Program (perangkat } \\
\text { lunak) } \\
\text { laptop/komputer }\end{array}$ & 27,5 & 58,5 & 31 \\
\hline $\begin{array}{l}\text { Sistem keamanan } \\
\text { komputer }\end{array}$ & 12 & 87 & 75 \\
\hline $\begin{array}{l}\text { Cara instalasi } \\
\text { laptop/komputer }\end{array}$ & 0 & 67 & 67 \\
\hline
\end{tabular}

Berdasarkan hasil penilaian post test dan menghitung peningkatan kemampuan dalam merakit dan istalasi laptop/komputer, secara umum para peserta telah mengetahui dasar-dasar perakitan komputer dan istalasi perangkat lunak dan telah mampu merakit serta melakukan instalasi laptop/komputer. Proses perakitan komputer dan pemasangan memori disajikan pada Gambar 1 dan 2.

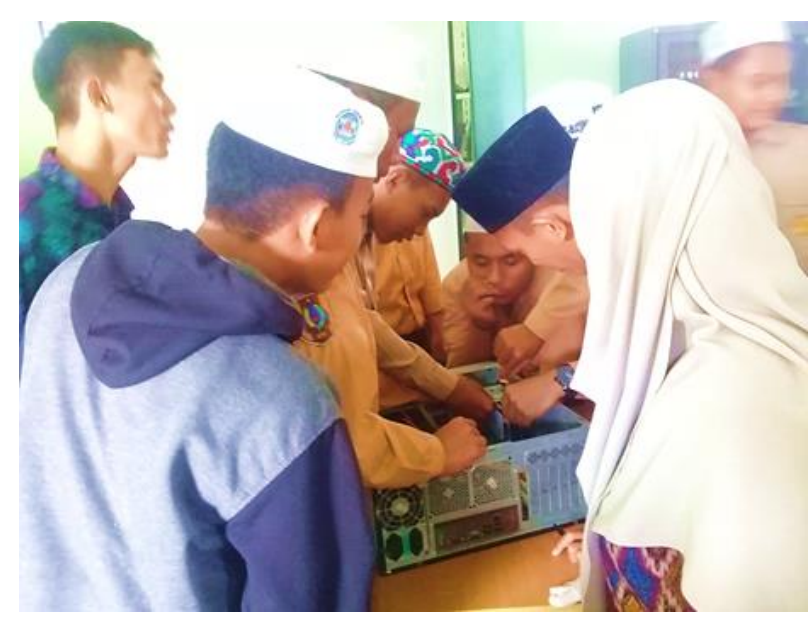

Gambar 1. Proses perakitan komputer

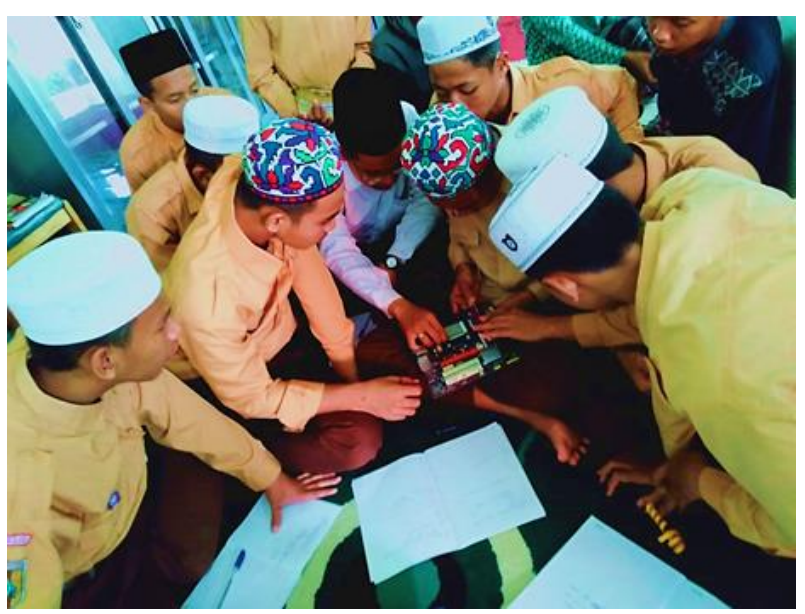

Gambar 2. Proses pemasangan memori

\section{KESIMPULAN}

Pelatihan ini memberikan beberapa materi yang terkait dengan pemahaman dalam merakit dan instalasi laptop/komputer untuk menambah kompetensi santri untuk memiliki keterampilan dalam bidang hardware dan software laptop/komputer. Materi yang disajikan dapat diterima, dicerna, dan dipahami peserta dengan baik. Jumlah peserta yang sebanding dengan jumlah pengabdi menjadikan pelatihan ini menjadi lebih kondusif. Kegiatan berlangsung lancar, tepat waktu dan sesuai dengan yang diharapkan dan para santri dapat berkomunikasi dengan para pembicara dan santri lain dengan baik.

\section{UCAPAN TERIMA KASIH}

Dalam pelaksanaan kegiatan pengabdian kepada masyarakat ini, penulis banyak mendapatkan dukungan dari berbagai pihak. Oleh karenanya dalam kesempatan ini penulis mengucapkan terima kasih yang sebesar besarnya kepada P2M Unisversitas Islam Kalimantan MAB Banjarmasin yang telah memberikan Dana Hibah melalui APBU Unisversitas Islam Kalimantan MAB Banjarmasin TA 2018/2019, Pimpinan Ponpes Wali Songo Banjarbaru dan peserta yang antusias mengikuti kegiatan ini. 


\section{REFERENSI}

Anjrah, Mintana, Wijaya, A. 2008. Keterampilan Komputer dan Pengelolaan Informasi (KKPI) Untuk SMK dan MAK Kelas X. Jakarta: Erlangga.

Arifianto, D., Funatik, A. 2009. Antigaptek Hardware Komputer : Pengenalan E Permasalahan + Solusi. Jakarta: Kawan Pustaka.

Azizah, S.N., Muhfiatun, M. 2017. Pengembangan Ekonomi Kreatif Berbasis Kearifan Lokal Pandanus Handicraft dalam Menghadapi Pasar Modern Perspektif Ekonomi Syariah (Study Case di Pandanus Nusa Sambisari Yogyakarta). Aplikasia: Jurnal Aplikasi Ilmu-Ilmu Agama. 17(2):63-78. https://doi.org/10.14421/aplikasia.v17i2.127 3

Budiman, H. 2017. Peran Teknologi Informasi Dan Komunikasi Dalam Pendidikan. AlTadzkiyyah: Jurnal Pendidikan Islam. 8(1):75-83. https://doi.org/10.24042/atjpi.v8i1.2095

Damanhuri, A., Mujahidin, E., Hafidhuddin, D. 2013. Inovasi Pengelolaan Pesantren dalam Menghadapi Persaingan di Era Globalisasi. Ta'dibuna: Jurnal Pendidikan Islam. 2(1):17-37. http://dx.doi.org/10.32832/tadibuna.v2i1.54 7

Daulay, M.S. 2007. Mengenal Hardware-Software dan Pengelolaan Instalasi Komputer. Yogyakarta: Andi Offset.

Gumawang, A. 2006. Belajar Merakit Komputer: Sebuah Panduan Sistematis, Jelas, dan Tuntas. Edisi Revisi. Bandung: Informatika.

Herlandy, P.B., Ismanto, E., Satria, A. 2019. Simulasi Pengenalan dan Instalasi PC berbasis Augmented reality dengan Metode Single marker. Journal of Education Informatic Technology and Science (JeITS). 1(2):85-96. https://doi.org/10.37859/jeits.v1i2.1390

Hidayat, N. 2010. Isu-Isu Kontemporer Pendidikan Islam Tentang Madrasah dan Tantangan Global. AlBidayah : Jurnal Pendidikan Dasar Islam. 2(1):4562. https://doi.org/10.14421/albidayah.v2i1.101

Jogiyanto, H.M. 2005. Pengenalan Komputer: Dasar Ilmu Komputer, Pemrograman, Sistem Informasi. Yogyakarta: Andi Offset.
Manurung, E.T., Lenny. 2014. Studi Atas Implementasi Sistem Informasi Berbasis Komputer Untuk Mengendalikan Kegiatan Pembelian Di Perusahaan Tekstil HM di Bandung. Bina Ekonomi: Majalah Ilmiah Fakultas Ekonomi Universitas Katolik Parahyangan. 18(1):28-42. https://doi.org/10.26593/be.v18i1.826.\%25p

Zaki, A., SmitDev Community. 2007. Cara Mudah Merakit PC. Jakarta: Elex Media Komputindo. 